\title{
Strategi Pengembangan Umkm Tenun Untuk Meningkatkan Sosial Ekonomi Di Kota Bima
}

\author{
Sri Ernawati ${ }^{1}$ \\ Sekolah Tinggi Ilmu Ekonomi Bima1 \\ Email Korespendensi : sriernawati.stiebima@gmail.com
}

\begin{abstract}
Abstrak : Dalam perekonomian Indonesia, Usaha Mikro, Kecil, dan Menengah (UMKM) adalah kelompok usaha yang memiliki jumlah paling besar, sebagai garda terdepan UMKM memiliki peranan di Indonesia bahkan ASEAN. Penelitian ini bertujuan untuk menganalisa perkembangan UMKM tenun untuk meningkatkan sosial ekonomi di Kota Bima. Jenis penelitian Deskriptif dengan pendekatan kualitatif. Pengumpulan data dengan melakukan wawancara, observasi dan dokumentasi adalah menggunakan. Analisa data dengan Matriks Internal Faktor Evaluation (IFE), Eksternal Faktor Evaluation (EFE), Analisis Matrik Internal Eksternal (IE) serta analisis Strenght, Weaknesses, Opportunities and Treaths (SWOT). Hasil penelitian menunjukan bahwa strategi pengembangan UMKM Tenun bisa dilakukan dengan terus melakukan ivonasi produk, kreativitas produk, memperluas jaringan pemasaran dan dukungan dari Pemerintah Kota Bima untuk terus mendukung dan mendampingin UMKM tenun agar terus berkembang.
\end{abstract}

Kata Kunci : Pengembangan UMKM, Tenun, sosial ekonomi

Paranan UMKM bagi sebuah negara diantaranya, pendistribusiaan pendapatan masyarakat, mampu mempertahankan dan mengembangkan unsur-unsur tradisi dan kebudayaan masyarakat setempat karena terciptanya kreatifitas, serta membantu dalam penyerapan tenaga kerja sehingga mampu mengurangi masalah pengangguran. Keberadaan UMKM tidak dapat dihapuskan ataupun dihindarkan dari masyarakat bangsa saat ini. Karena keberadaannya sangat bermanfaat dalam hal pendistribusian pendapatan masyarakat. Selain itu juga mampu menciptakan kreatifitas yang sejalan dengan usaha untuk mempertahankan dan mengembangkan unsur-unsur tradisi masyarakat setempat. Pada sisi lain, UMKM mampu menyerap tenaga kerja dalam skala yang besar mengingat jumlah penduduk Indonesia yang besar sehingga hal ini dapat mengurangi tingkat pengangguran. Dari sinilah terlihat bahwa keberadaan UMKM yang bersifat padat karya, menggunakan teknologi yang sederhana dan mudah dipahami mampu menjadi sebuah wadah bagi masyarakat untuk bekerja, (4)

Sektor UMKM di Indonesia diatur dalam Undang-undang nomor 20 tahun 2008 tentang Usaha Mikro, Kecil, dan Menengah (5). Undangundang ini menjadi acuan untuk pemberdayaan dan pengembangan UMKM di Tanah Air. Aturan lainnya adalah Peraturan Pemerintah Republik Indonesia Nomor 17 Tahun 2013 tentang Pelaksanaan Undangundang Nomor 20 Tahun 2008 tentang Usaha Mikro, Kecil, dan Menengah. Peraturan Pemerintah tersebut mengatur lebih lanjut perihal pengembangan usaha, kemitraan, perizinan, serta koordinasi dan pengendalian UMKM 
Dalam aturan tersebut dijelaskan kriteria UMKM di Indonesia. Usaha mikro didefinisikan sebagai usaha produktif milik perseorangan atau badan usaha perseorangan yang memenuhi kriteria usaha mikro. Sedangkan, usaha kecil didefinisikan sebagai kegiatan ekonomi produktif yang berdiri sendiri. Usaha ini dilakukan perorangan atau badan usaha yang bukan merupakan anak perusahaan atau bukan cabang perusahaan yang dimiliki, dikuasai atau menjadi bagian baik langsung maupun tidak langsung dari usaha menengah atau usaha besar serta memenuhi kriteria lain. (2)

Secara umum, UMKM menghadapi berbagai kendala dalam pengembangan usahanya. Beberapa kendala yang dihadapi UMKM di antaranya adalah: permodalan, pemasaran, bahan baku, teknologi, manajemen, birokrasi, infrastruktur, dan kemitraan. Kendala-kendala ini merupakan faktor menurunnyakinerja. Penurunan kinerja dapat membuat organisasi berproduksi secara tidak efektif dan efesien serta tidak dapat mencapai tujuannya secara maksimal, sehingga perlu dilakukan perbaikan kinerja untuk meningkatkan kualitas dari UMKM (6)

Seperti hasil penelitian (7) yang menyatakan bahwa UMKM memiliki titik kelemahan yang harus segera diselesaikan meliputi kurangnya permodalan baik jumlah maupun sumbernya, kurangnya kemampuan manajerial dan minimnya keterampilan pengoperasi dalam mengorganisir dan terbatasnya pemasaran merupakan hal yang mendasar selalu dihadapi oleh semua UMKM dalam merintis sebuah usaha bisnis untuk dapat berkembang. Persaingan bisnis yang kurang sehat dan desakan ekonomi sehingga mengakibatkan ruang lingkup usaha menjadi sempit dan terbatas merupakan faktor tambahan yang merupakan pekerjaan rumah yang harus diselesaikan oleh semua pihak khususnya Pemerintah sebagai pemangku kepentingan secara lokal dan nasional.

Pada masyarakat dimana budaya juga dapat dijadikan sebagai symbol baik untuk stutus sosial maupun motivasi dari diri masyarakat itu sendiri. Memanfaatkan budaya untuk mengembangna peningkatan omzet pemdapatan UMKM sekarang bukan hal yang tabu. Banyak kegiatankegiatan kebudayaan yang berpotensi meningkatkan penghasilan UKMK seperti budaya membatik, dimana kain batik bisa di jual trus kain batik dijadikan berbagai macam produk seperti baju, tas dan sepatu, Budaya tarian di bali yang bisa dijadikan sebagai factor pendukung pariwisata sehinggan UMKM kuliner, kerajinan tangan bisa berkembang dengan pesat, begitu juga terjadi di Kota Bima, dengan perkembangan UMKM tenun mengakibatkan kehidupan social penenun bisa meningkat.

Dalam pengembangan UMKM Tenun di Kota Bima yang berjumlah 1.534 pada tahun 2019, langkah ini tidak semata-mata merupakan langkah yang harus diambil oleh Pemerintah dan hanya menjadi tanggung jawab Pemerintah. Pihak UMKM sendiri sebagai pihak internal yang dikembangkan, dapat mengayunkan langkah bersama-sama dengan Pemerintah. Karena potensi yang mereka miliki mampu menciptakan 
kreatifitas usaha dengan memanfaatkan fasilitas yang diberikan oleh pemerintah sehingga menghapkan agar pemerintah daerah Kota Bima selalu rutin melaksanakan event-event kebudayaan, pameran agar dapat meningkatkan pendapatan UMKM yang ada di Kota Bima., karena stiap kegiatan yang dilakukan pasti akan mendatangkan multiplayer efek untuk kehidupan masyarakat. Dari uraian yang dijelaskan penelitian ini bertujuan untuk untuk menganalisa upaya perkembangan UMKM tenun untuk meningkatkan kondisi sosial ekonomi penenun di Kota Bima. sehingga judul penelitian yang peneliti angkat yaitu Pengembangan UMKM Tenun Untuk Meningkatkan Sosial Ekonomi di Kota Bima

\section{METODE}

Metode deskriptif dengan pendekatan kualitatif merupakan jenis penelitian yang digunakan oleh peneliti. Maksud dari penelitian ini agar peneliti dapat menggambarkan keadaan yang sebenarnya sesuai dengan kenyataan, menggali dan menganalisis lebih mendalam terkait strategi pengembangan UMKM Tenun untuk meningkatkan social ekonomi penenun. Wawancara, observasi dan dokumentasi adalah pendekatan kualitatif yang dilakukan oleh penelit. Analisis data menggunakan analisis Matriks Internal Faktor Evaluation (IFE), Eksternal Faktor Evaluation (EFE), Analisis Matrik Internal Eksternal (IE) serta analisis Strenght, Weaknesses, Opportunities and Treaths (SWOT). Menurut (8), analisis SWOT mengidentifikasi berbagai faktor secara sistematik untuk merumuskan strategi yang didasarkan pada logika untuk memaksimalkan kekuatan dan peluang yang dimiliki dan secara bersamaan mampu meminimalkan kelemahan dan ancaman yang berasal dari internal dan eksternal

\section{HASIL}

\section{Analisis Matrik IFE}

Untuk melihat bagaimana analisis perkembangan UMKM Tenun dilihat dari faktor Internal. Bisa dilihat ada matrik IFE dibawah ini

Tabel 1. Analisis Matrik IFE

\begin{tabular}{|c|c|c|c|c|}
\hline No & Faktor Internal & $\begin{array}{l}\text { Rating } \\
\text { (a) }\end{array}$ & $\begin{array}{l}\text { Bobot } \\
\text { (b) }\end{array}$ & $\begin{array}{l}\text { Skor } \\
\text { (axb) }\end{array}$ \\
\hline & Strenght (S) & & & \\
\hline 1 & $\begin{array}{l}\text { UMKM Tenun merupakan wadah paling } \\
\text { menjanjikan bagi ibu-ibu yang mempunyai keahlian } \\
\text { menenun }\end{array}$ & 3,50 & 0,11 & 0,385 \\
\hline 2 & UMKM usaha yang mandiri, kokoh dan fleksibek & 3,10 & 0,10 & 0,310 \\
\hline 3 & $\begin{array}{l}\text { Promosi produk UMKM Tenun sudah } \\
\text { memanfaatkan media social }\end{array}$ & 3,65 & 0,12 & 0,438 \\
\hline 4 & $\begin{array}{l}\text { Produk yang dihasilkan hand Made (Buatan } \\
\text { Tangan) }\end{array}$ & 4,00 & 0,11 & 0,440 \\
\hline 5 & $\begin{array}{l}\text { Motif yang dihasilkan sudah cukup banyak } \\
\text { Weakness (W) }\end{array}$ & 3,50 & 0,12 & 0,420 \\
\hline 1 & Harga lumayan Mahal & 2,00 & 0,11 & 0,220 \\
\hline 2 & Proses produksi relatif lama & 1,75 & 0,11 & 0,192 \\
\hline 3 & Menenun merupakan pekerjaan sampingan & 1,50 & 0,10 & 0,165 \\
\hline
\end{tabular}


$4 \quad$ Pendidikan pekerja UMKM Tenun masih relatif

2,80

$0,12 \quad 0,308$ rendah

Total

$1,00 \quad 2,878$

Sumber : Olahan Data Primer (2020)

Total Skor yang diperoleh dari matrik IFE berada pada skor 2,02,99 yaitu sebesar 2,878 yang berarti bahwa kondisi Internal UMKM Tenun di Kota Bima cukup kuat mampu untuk berkembang dan mengatasi kelemahan yang dimiliki.

Analisis Matrik EFE

Untuk melihat bagaimana analisis perkembangan UMKM Tenun dilihat dari faktor Eksternal. Bisa dilihat ada matrik EFE dibawah ini:

Tabel 2. Analisis Matrik EFE

\begin{tabular}{|c|c|c|c|c|}
\hline $\begin{array}{l}\mathbf{N} \\
\mathbf{O}\end{array}$ & Faktor Ekternal & $\begin{array}{l}\text { Rating } \\
\text { (a) }\end{array}$ & $\begin{array}{c}\text { Bobot } \\
\text { (b) }\end{array}$ & $\begin{array}{l}\text { Skor } \\
\text { (axb) }\end{array}$ \\
\hline & Opportunities (0) & & & \\
\hline 1 & Potensi Pasar Besar & 3,10 & 0,12 & 0,372 \\
\hline 2 & Akses ke lokasi UMKM lancar & 3,50 & 0,17 & 0,595 \\
\hline 3 & $\begin{array}{l}\text { Meningkatnya kesadaran masyrakat untuk } \\
\text { mengkoleksi Kain tenun }\end{array}$ & 3,00 & 0,16 & 0,480 \\
\hline 4 & $\begin{array}{l}\text { Kain tenun sudah banyak di inovasi menjadi } \\
\text { brbagai produk seperti tas, sepatu, jilbab, baju } \\
\text { dll } \\
\text { Threats (T) }\end{array}$ & 3,70 & 0,17 & 0,629 \\
\hline 1 & Pesaing dengan UKMK sejenis dari daerah lain & 2,10 & 0,14 & 0,294 \\
\hline 2 & $\begin{array}{l}\text { UMKM Tenun yang masih bergantung pada } \\
\text { bantuan bahan baku dari pemerintah }\end{array}$ & 2,75 & 0,11 & 0,302 \\
\hline \multirow[t]{2}{*}{3} & $\begin{array}{l}\text { Festival/Event dilaksanakan pada saat tertentu } \\
\text { saja }\end{array}$ & 1,50 & 0,13 & 0,195 \\
\hline & Total & & 1,00 & 2,867 \\
\hline
\end{tabular}

Sumber : Olahan Data Primer (2020)

Skor yang didapatkan pada matrik EFE berada pada skor 2,0-2,99 sebesar 2,867. Hal ini menunjukan bahwa dengan adanya event-event budaya rimpu di Kota Bima mampu mengatasi acaman-ancaman yang timbul dengan memanfaatkan peluang yang ada.

Analisis Matrik IE

Untuk melihat bagaimana analisis perkembangan UMKM Tenun dilihat analisis factor internal dan eksternal. Bisa dilihat ada matrik IE dibawah ini

Tabel 3. Analisis Matrik IE

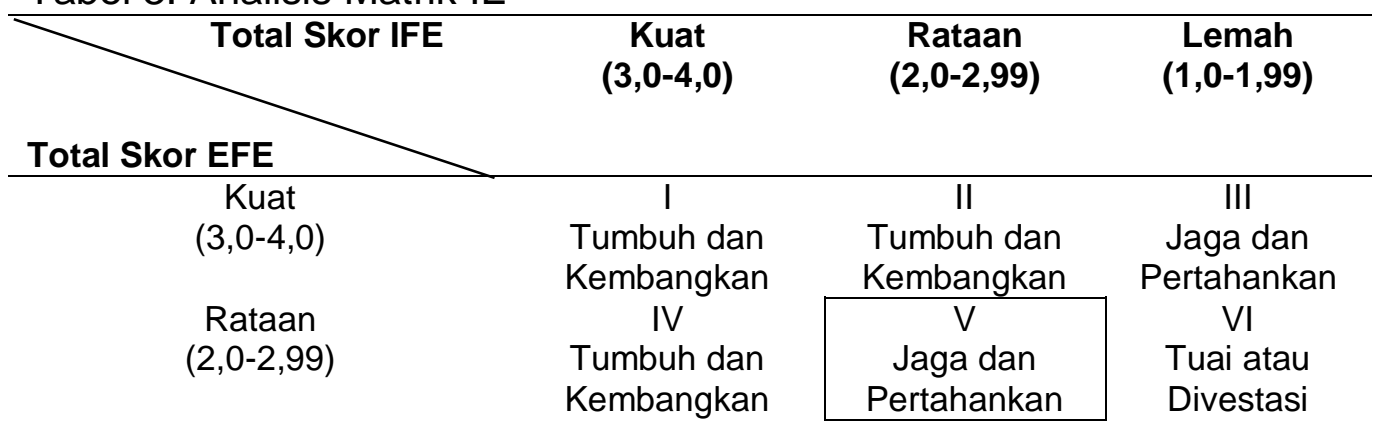


Lemah
$(1,0-1,99)$
VII
Jaga dan
Pertahankan

Pertahankan

\begin{tabular}{cc} 
VIII & XI \\
Tuai atau & Tuai atau \\
Divestasi & Divestasi \\
\hline
\end{tabular}

Sumber : Olahan Data Primer (2020)

Matrik internal dan eksternal disususn dari total skor matrik IFE dan EFE (2,878 dan 2,867). Hal ini dapat menunjukan bahwa posisi UMKM Tenun berada pada kuadran $\mathrm{V}$ posisis ini menunjukan bahwa UMKM tenun bisa terus berkembang dengan menjaga dan mempertahankan keberadaan fertival budaya rimpu.

\section{Analisis Matriks SWOT}

Matriks SWOT menghasilkan empat tipe strategi, yaitu strategi SO (Strenghts-Opportunities), strategi WO (Weaknesses-Opportunities), strategi ST (Strenghts-Threats) dan strategi WT (Weaknesses-Threats), seperti dimuat pada Tabel 4.

Tabel 4. Matrik SWOT

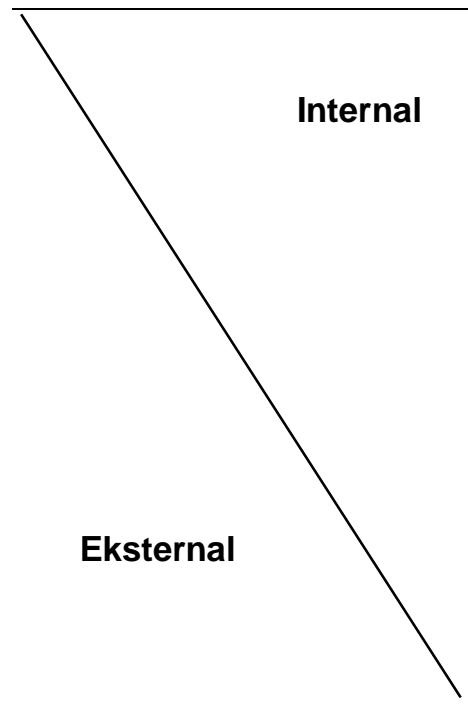

1. UMKM Strenght (S) merupakan wadah paling menjanjikan bagi ibu-ibu yang keahlian menenun mempunyai

2. UMKM usaha mandiri, kokoh dan fleksibek

3. Promosi produk UMKM Tenun sudah memanfaatkan media social

4. Produk yang dihasilkan hand Made (Buatan Tangan)

5. Motif yang dihasilkan sudah cukup banyak

Opportunities (0)

1. Potensi Pasar Besar

2. Akses ke lokasi UMKM lancer

3. Meningkatnya kesadaran masyrakat untuk mengkoleksi Kain tenun

4. Kain tenun sudah banyak di inovasi menjadi berbagai produk seperti tas, sepatu, jilbab, baju dll

\section{Strategi SO}

1. Produksi harus dilakukan memenuhi pasar (S1, S5, O1,O3, O4)

2. Meningkatkan Diversivikasi tenun (S2, S4,S5, O4)

3. Mempercepat distribusi ke konsumen dengan menambah jaringan penjualan $(\mathrm{S} 3, \mathrm{O} 2, \mathrm{O} 3)$

\section{Weakness (W)}

1. Harga lumayan Mahal

2. Proses produksi relatif lama

3. Menenun merupakan pekerjaan sampingan

4. Pendidikan pekerja UMKM Tenun masih relatif rendah

\section{Strategi WO}

terus 1. Menjalin kerjasama untuk dengan UMKM lain yang memerlukan kain tenus sebagai bahan produksinya (W1, W4, O3)

2. Diberikan pelatihan sehingga termotivasi untuk meningkatkan UMKM nya agar lebih produktif lagi (W2, W3, $\mathrm{O} 3, \mathrm{O} 4)$

3. Membantu pemasaran produk melalui 
partisipasi saat event, pameran di luar daerah (W1, 01,02)

Threats (T)

1. Pesaing dengan UKMK sejenis dari daerah lain

2. UMKM Tenun yang masih bergantung pada bantuan bahan baku dari pemerintah

3. Festival/Event

dilaksanakan pada saat tertentu saja

\section{Strategi ST}

1. Mengikuti pameran produk lokal UMKM di Luar Daerah (S3, S4, S5, T1)

2. Selalu Up Date event yang diadain Pemerintah Daerah agar bisa berperan serta (S5, T3)

3. Mendaftarkan UMKM yang dibentuk ke Dinas terkait agar diakui keberadaannya (S1, S2,

\section{Strategi WT \\ 1. Terus Berinovasi melahirkan motif baru yang bernuansa kearifan lokal (W1, T1)}

2. Menjalain kerja sama dengan jejaring online shop (W4, T3)

3. Sering memngikuti pelatihan yang diadakan pemerintah daerah, lembaga pemberdayaan (W2, W3, T2)

Sumber : Olahan Data Primer (2020)

Dari analasis SWOT pemerintah Kota Bima harus melakukan berbagai terobosan trategis untuk meningkatkan perkembangan UMKM. Langkah strategi untuk strategi SO memaparkan bahwa UMKM Tenun harus terus berproduksi, meningkatkan diversifikasi produk dan mempercepat distribusi produk ke tangan konsumen. Strategi WO memaparkan bahwa UMKM harus mampu berkerja sama dengan UMKM yang memproduksi produk yang menggunakan kain tenus sebagai bahan baku produksinya, Pemerintah Daerah Kota Bima harus berperan aktif memberikan pelatihan untuk memotivasi , membantu pemasaran dengan mengikut sertakan UMKM saat event atau pameran di luar daerah. Strategi ST menjelaskan bahwa UMKM harus mengikuti berbagai kegiatan seperti event-event dan pameran agar produk UMKM tenun bisa dikenal dan mendaftarkan usaha nya ke Dinas terkait agar di data sehingga dianggap legal dan diakui keberadaannya. Strategi WT menjelaskan bahwa produk yang dihasilkan UMKM Tenun harus terus berinovasi dari segi corak maupun warna, membangun jaringan dengan agen online shop dan mengikuti berbagai maca pelatihan untuk meningkatkan kemitraan dan keilmuan

\section{PEMBAHASAN}

Dari Hasil penelitian dapat dinyatakan bahwa Keberadaan UMKM tidak dapat dihapuskan ataupun dihindarkan dari masyarakat bangsa saat ini. Karena keberadaannya sangat bermanfaat dalam hal pendistribusian pendapatan masyarakat. Selain itu juga Mampu menciptakan kreatifitas yang sejalan dengan usaha untuk mempertahankan dan mengembangkan unsur-unsur tradisi dan kebudayaan masyarakat setempat. Pada sisi lain, UMKM mampu menyerap tenaga kerja dalam skala yang besar mengingat jumlah penduduk Indonesia yang besar sehingga hal ini dapat mengurangi tingkat pengangguran. Dari sinilah terlihat bahwa keberadaan UMKM yang 
bersifat padat karya, menggunaka teknologi yang sederhana dan mudah dipahami mampu menjadi sebuah wadah bagi masyarakat untuk bekerja.

Pengembangan UMKM menjadi sangat strategis dalam menggerakkan perekonomian nasional, mengingat kegiatan usahanya mencakup hampir semua lapangan usaha sehingga kontribusi UMKM menjadi sangat besar bagi peningkatan pendapatan bagi kelompok masyarakat berpendapatan rendah. Begitu juga dengan pengembangan UMKMK Tenun di Kota Bima dengan memanfaatkan festival-festival budaya seperti budayayang mampu memberikan kontribusi untuk meningkatkan permintaan kain tenun sehingga pendapatan UMKM Tenun bisa meningkat.

Hasil analisis IFE menyatakan bahwa kondisi Internal UMKM Tenun di Kota Bima cukup kuat mampu untuk berkembang dan mengatasi kelemahan yang dimilik dan analisis EFE menunjukan bahwa dengan adanya event-event budaya rimpu di Kota Bima mampu mengatasi acaman-ancaman yang timbul dengan memanfaatkan peluang yang ada. Analsis IE menunjukan bahwa posisi UMKM Tenun pada kuadran $\mathrm{V}$ dimana posisis ini menunjukan bahwa UMKM tenun bisa terus berkembang dengan menjaga dan mempertahankan keberadaan fertival budaya rimpu dan dari hasil analisis SWOT menunjukan bahwa perkembangan UMKM tenun dilihat dapat berkembang dengan campur tangan Pemerintah Daerah Kota Bima sehinggan UMKM tenun dapat menghadapi tantangan dan acaman serta menjadikan kelebihan serta peluang untuk meningkatkan pendapatnya. Pemrintah daerah dapat memberikan berbagai pelatihan untuk meningkatkan skill, memotivasi agar kesadaran pelaku UMKM meningkat dimana UMKM bisa dijadikan sebagai peluang usaha prioritas bukan hanya sekedar usaha sampingan dan sering mengikuti event-event seperti pameran untuk memperkenalkan produk UMKM dan memperluas wilayah pemasaran baik secara offline maupun online.

\section{KESIMPULAN}

Berdasarkan hasil penelitian dapat disimpulkan bahwa Upaya pengembangan UMKM Tenun untuk meningkat social ekonomi penenun di Kota Bima bisa terjadi, Hal ini bisa dibuktikan dengan analisis Internal Eksternal (IE) yang menyatakan bahwa perkembangan UMKM tentu bisa terus berkembang,dipertahannya dan dijaga keberadaannya. Hasil penelitian menunjukan bahwa strategi pengembangan UMKM Tenun bisa dilakukan dengan terus melakukan inovasi produk, kreativitas produk, memperluas jaringan pemasaran dan dukungan dari Pemerintah Kota Bima untuk terus mendukung dan mendampingin UMKM tenun agar terus berkembang.

\section{REFERENSI}

Agusetyaningrum, V., Mawardi, M. K., \& Pangestuti, E. (2016). Strategi Pengem-bangan USAha Kecil Dan Menengah (UKM) Untuk 
Meningkatkan Citra Kota Malang Sebagai Destinasi Wisata Kuliner (Studi Pada UKM Berbasis Ku-liner Kota Malang). Jurnal Administrasi Bisnis, Vol. 38 No. 2: 105-111.

Purwanto Antonius, (16 september 2020). Potret dan Tantangan UMKM di Indonesia. https://kompaspedia.kompas.id/baca/paparan-topik/potretdan-tantangan-umkm-di-indonesia.

Padyanawati Diah Ayu dan Hardjomidjojo Hartrisari, (2019). Strategi Peningkatan Daya Saing Usaha Mikro, Kecil, Dan Menengah Di Desa Tegalwaru, Kabupaten Bogor. Jurnal Rekayasa dan Manajemen Agroindustri Vol. 7, No.1, 153-168, ISSN : 2503-488X

Anggraeni Dwi Feni, Hardjanto lama dan Hayat Ainul, (2013). Pengembangan Usaha Mikro, Kecil Dan Menengah (Umkm) Melalui Fasilitasi Pihak Eksternal dan Potensi Internal (Studi Kasus Pada Kelompok Usaha "Emping Jagung" Di Kelurahan Pandanwangi Kecamatan Blimbing Kota Malang. Jurnal Administrasi public Vol. 1 N0.6 1286-1295

Undang-Undang No.20 Pasal 1 dan Pasal 6 Tahun 2008 http://www.hukumonline.com/pusa tdata/download/fl56041/node/2802 9 . Diakses 12 Desember 2020

Damayanti Annisa. (2017). Analisis Indeks Kinerja Usaha Mikro, Kecil, dan Menengah (UMKM) Agroindustri di Kota Bogor. [SKRIPSI]. Bogor:Institut Pertanian Bogor.

Suci Rahmini Yuli, 2017. Perkembangan Umkm (Usaha Mikro Kecil dan Menengah) Di Indonesia. Jurnal IImiah Cano Ekonomos Vol. 6 No. 1 . Hal 51-58

Rangkuti Freddy. 2015. Analisis SWOT. Jakarta : PT Gramedia Pustaka Utama. 